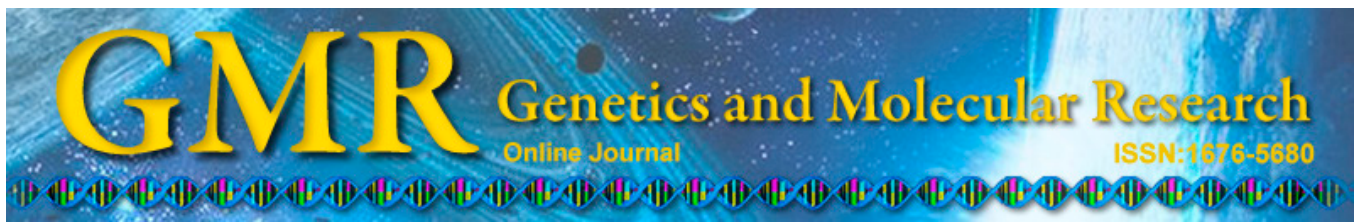

\title{
Cytogenetic characterization of species of the family Heptapteridae (Teleostei: Siluriformes) from the Cuiabá and Ivaí River Basins, Brazil
}

\author{
L.M. Barbosa, G.E.B. Ferreira, A.C. Prizon, A.L.B. Portela-Castro and \\ I.C. Martins-Santos
}

Laboratório de Citogenética de Peixes, Departamento de Biotecnologia, Genética e Biologia Celular, Universidade Estadual de Maringá, Maringá, PR, Brasil

Corresponding author: L.M. Barbosa

E-mail: ligia_magrinelli@hotmail.com.br / ligiamagrinelli@gmail.com

Genet. Mol. Res. 14 (3): 8640-8649 (2015)

Received October 1, 2014

Accepted March 5, 2015

Published July 31, 2015

DOI http://dx.doi.org/10.4238/2015.July.31.12

\begin{abstract}
We cytogenetically characterized three species of Heptapteridae (Pimelodella sp, Pimelodella taenioptera, and Imparfinis schubarti) by investigating the distribution of constitutive heterochromatin and nucleolar organizer regions by silver nitrate impregnation (Ag-NOR) and fluorescence in situ hybridization. Pimelodella sp showed had a diploid number $(2 \mathrm{n})=46$ chromosomes, $26 \mathrm{~m}+10 \mathrm{sm}+$ $10 \mathrm{st}$, and $\mathrm{FN}=92 ; P$. taenioptera, $2 \mathrm{n}=52$ chromosomes, $26 \mathrm{~m}+22 \mathrm{sm}$ +4 st, and $\mathrm{FN}=104$; and $I$. schubarti, $2 \mathrm{n}=58$ chromosomes, $28 \mathrm{~m}+$ $28 \mathrm{sm}+2 \mathrm{st}$, and FN $=116$. The two Pimelodella species had Ag-NORs sites on the submetacentric pair 14, located on the short arm in terminal position. In I. schubarti, the Ag-NORs sites were in an interstitial position on the long arm of the metacentric pair 1. C-banding revealed that Pimelodella sp contained a small amount of constitutive heterochroma-
\end{abstract}


tin, whereas $P$. taenioptera contained a higher number of heterochromatic regions, in the pericentromeric, interstitial, and telomeric positions. I. schubarti had markers in centromeric and telomeric regions of a few chromosomes, and a large pericentromeric block on pair 1. Fluorochrome chromomycin $\mathrm{A}_{3}\left(\mathrm{CMA}_{3}\right)$ staining revealed positive signals on pair 14 in both Pimelodella species. Treatment with 4',6-diamidino2-phenylindole (DAPI) revealed no markings in P. taenioptera, but an interstitial marking on the long arm of pair 14 in Pimelodella sp. In I. schubarti, positive signals of $\mathrm{CMA}_{3}$ were detected in the first pair, but negative signals were detected for DAPI staining. These results contribute to the karyotypic description of the less-studied species in the Brazilian Midwest.

Key words: Heptapteridae; Karyotype; Chromomycin $\mathrm{A}_{3}$; Nucleolar organizer regions; 4',6-diamidino-2-phenylindole; Fluorescence in situ hybridization

\section{INTRODUCTION}

The order Siluriformes (catfish) are highly diverse, with approximately 5705 species in 37 families (Eschmeyer and Fong, 2013), including the family Heptapteridae, which includes small- and medium-sized fish. Lundberg et al. (1991) and Pinna (1998) established three monophyletic groups within the family Pimelodidae, corresponding to the Pimelodinae, Heptapterinae (Rhamdiinae), and Pseudopimelodinae subfamilies; however, these were elevated to family status by Ferraris (2007). The Heptapteridae consists of about 26 genera and 189 species, 52 of which have not yet been described (Bockmann and Guazelli, 2003). The heptapterids are endemic to the Neotropics, and are one of the most representative groups of the order Siluriformes in Central and South America. Among the genera of this family, Pimelodella is one of the most diverse, with approximately 60 species (Burgess, 1989), and the genus Imparfinis includes approximately 28 species (Lundberg et al., 1991).

Despite the high number of species in the Heptapteridae, cytogenetic data are scarce, with few karyotypic studies conducted on these species. However, this group exhibits great chromosomal diversity, with a diploid number of $2 \mathrm{n}=42$ in Imparfinis hollandi (Margarido and Moreira-Filho, 2008) to $2 \mathrm{n}=62$ chromosomes in Rhamdia hilarii (Toledo and Ferrari, 1976). However, $2 n=58$ chromosomes is the most frequent value found in this family.

The phylogenetic relationships of the Heptapteridae are not well known, since the taxonomy of the species is complex and still poorly defined with respect to their genera (Bockmann and Guazzelli, 2003). Cytogenetics has been shown to be an important cytotaxonomic tool, and is a valuable contribution to the study of systematics, as well as to the identification of cryptic species and taxa.

This study aimed to cytogenetically characterize three species of the Heptapteridae (Pimelodella sp, Pimelodella taenioptera, and Imparfinis schubarti) by investigating the distribution of constitutive heterochromatin and nucleolar organizer regions (NORs) by silver nitrate impregnation (Ag-NOR) and fluorescence in situ hybridization (FISH), in order to elucidate the evolutionary processes in the group as well for future phylogenetic studies of this family. 


\section{MATERIAL AND METHODS}

Twelve specimens (eight males and four females) of Pimelodella sp. were collected from the Cuiabá River Basin, Mato Grosso, Brazil. This species is found in deep wells on the left bank of the Cuiabá River. Eighteen specimens (eleven males and seven females) of P. taenioptera were collected from the Aricá Mirim River, which is a tributary of the Cuiabá River. Eight specimens (six males and two females) of I. schubarti were collected from the Ivaí River Basin, PR, Brazil.

The cytogenetic analysis of mitotic chromosomes was based on conventional techniques and chromosome banding. The chromosomes were classified as metacentric (M), submetacentric (SM), or subtelocentric (ST), according to the methodology proposed by Levan et al. (1964), and all chromosomes with two arms were included for the calculation of the fundamental number (FN). Mitotic chromosomes were obtained from preparations of the cephalic part of the kidney by the "air-drying" technique, modified for fish by Bertollo et al. (1978). Identification of NORs was conducted by staining with silver nitrate (Howell and Black, 1980). The detection of DNAr sites was conducted by following the techniques described by Heslop-Harrison et al. (1991) and Cuadrado and Jouve (1994). We obtained 18S rDNA probes by amplifying and cloning fragments from Oreochromis niloticus. Base-specific fluorochrome staining methods using chromomycin $\mathrm{A}_{3}\left(\mathrm{CMA}_{3}\right)$ and 4',6-diamidino-2-phenylindole (DAPI) were performed, according to the methods described by Schmid (1980) and Schweizer (1976), respectively. The distribution patterns of heterochromatin were ascertained following the technique described by Sumner (1972). Giemsa staining was replaced by propidium iodide staining, following the method used by Lui et al. (2009).

The preserved specimens (Pimelodella sp, NUP 14703; P. taenioptera, NUP 14702; and I. schubarti, NUP 14701) were deposited in the Núcleo de Pesquisas em Limnologia, Ictiologia e Aquicultura (Nupélia) of the Universidade Estadual de Maringá, Maringá, PR, Brazil.

\section{RESULTS}

Pimelodella sp. had a diploid number of $2 \mathrm{n}=46$ chromosomes and P. taenioptera had $2 \mathrm{n}=52$ chromosomes, with karyotype formulas of $26 \mathrm{~m}+10 \mathrm{sm}+10 \mathrm{st}$ and $\mathrm{FN}=92$ and $26 \mathrm{~m}+22 \mathrm{sm}+4 \mathrm{st}$ and $\mathrm{FN}=104$, respectively. I. schubarti had a diploid number of $2 \mathrm{n}=58$ chromosomes with a karyotype formula of $28 \mathrm{~m}+28 \mathrm{sm}+2 \mathrm{st}$ and $\mathrm{FN}=116$. Morphologically distinguishable sex chromosomes were not observed in any of the three species.

In Pimelodella sp. C-banding revealed that there was a small amount of constitutive heterochromatin restricted to pair 14, which was located in the interstitial region of the long arm and was not coincident with the Ag-NOR (Figure 1a and b). P. taenioptera contained a higher number of heterochromatic regions, which were located in pericentromeric, interstitial, and telomeric positions. Interstitial bands mainly occurred on the pairs 1, 2, 3, 4, 14, 20, 21, 22 , and 23 (Figure $2 \mathrm{a}$ and $\mathrm{b}$ ). We found a large block on the long arm of pair 6 , which was more strongly stained on one of the homologs, and was also observed by FISH 18S using propidium iodide staining. 
a)

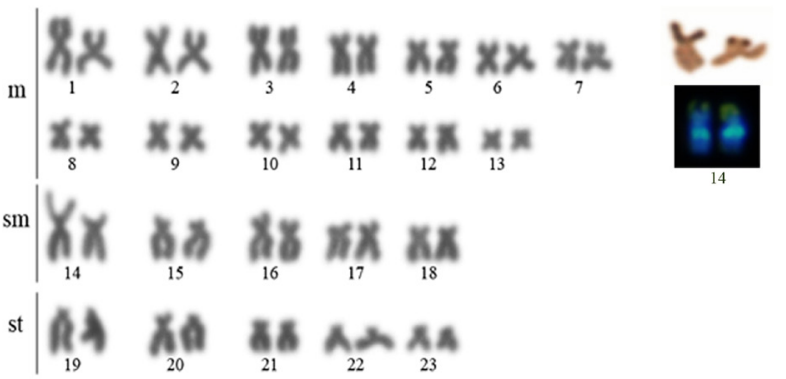

b)

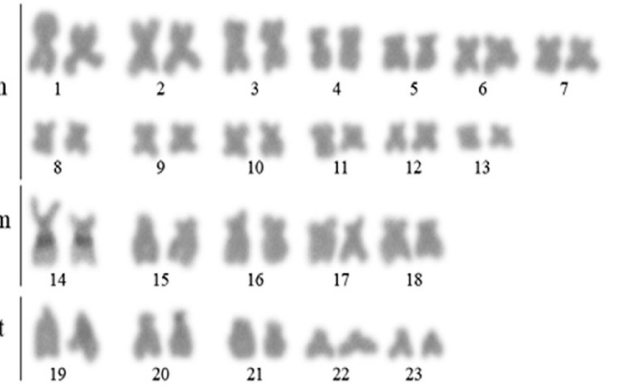

Figure 1. Karyotypes of Pimelodella sp. with Giemsa staining (a) and C-banding (b). In detail, the silver nucleolar organizer region (Ag-NOR)-bearing chromosome pair and 4',6-diamidino-2-phenylindole-chromomycin $\mathrm{A}_{3}$ (DAPI-CMA $)$ staining.

a)
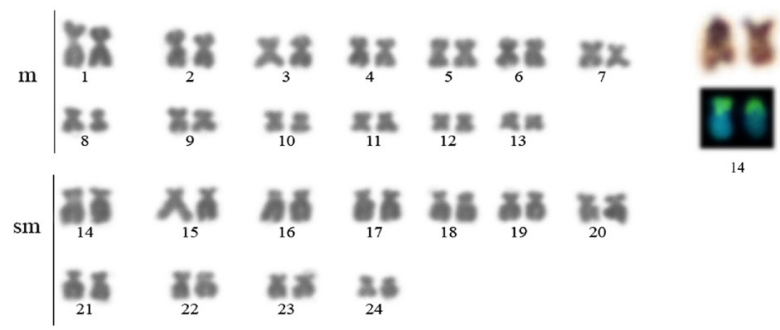

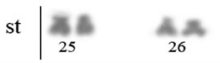

b)

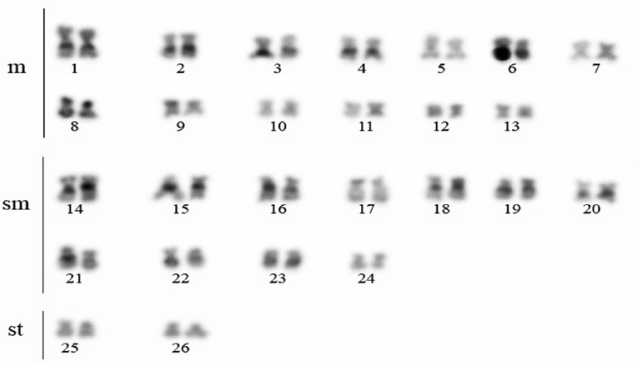

Figure 2. Karyotypes of Pimelodella taenioptera with Giemsa staining (a) and C-banding (b). In detail, the silver nucleolar organizer region (Ag-NOR)-bearing chromosome pair and 4',6-diamidino-2-phenylindole-chromomycin $\mathrm{A}_{3}\left(\mathrm{DAPI}-\mathrm{CMA}_{3}\right)$ staining. 
The constitutive heterochromatin analysis revealed that I. schubarti contained markers in the centromeric and telomeric regions of a few chromosomes; however, there was a large pericentromeric block on the long arm of the first pair of metacentric chromosomes, coincident with the secondary constriction (Figure $3 \mathrm{a}$ and $\mathrm{b}$ ).

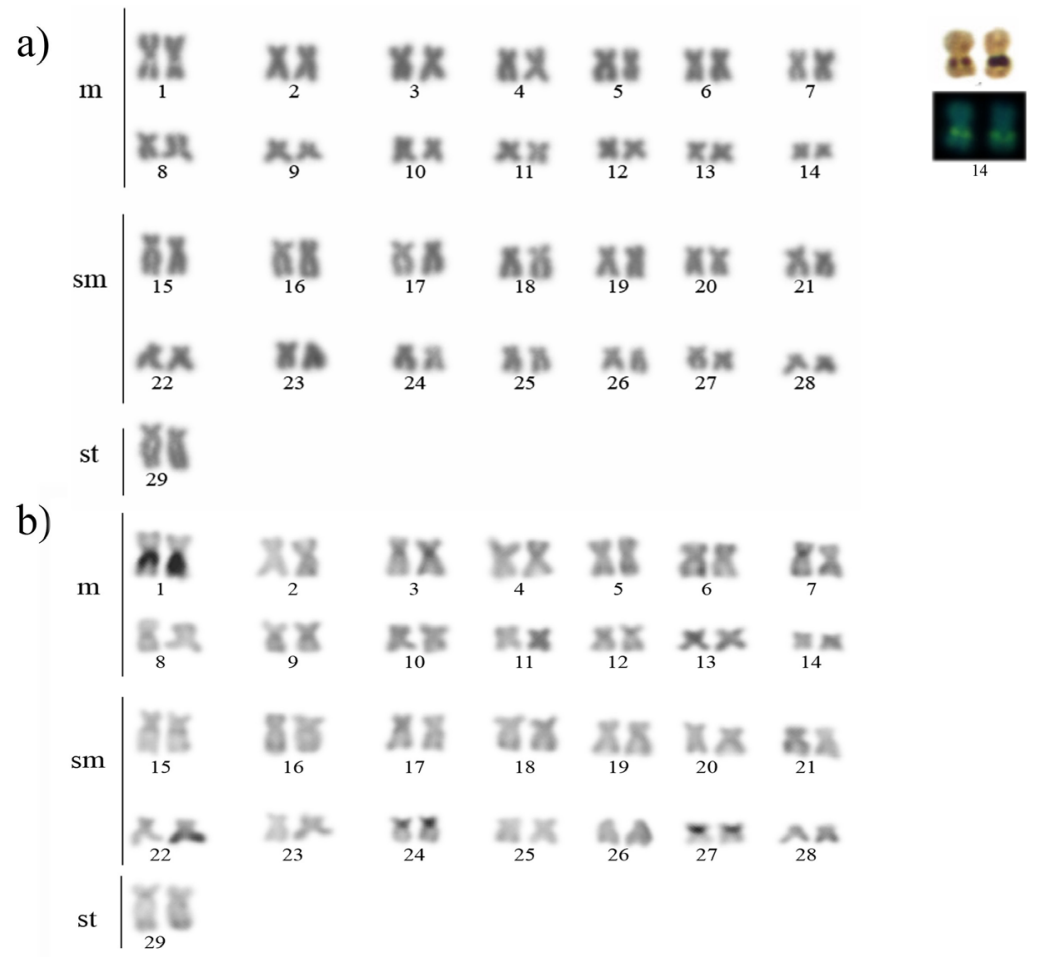

Figure 3. Karyotypes of Imparfinis schubarti with Giemsa staining (a) and C-banding (b). In detail, the silver nucleolar organizer region (Ag-NOR)-bearing chromosome pair and 4',6-diamidino-2-phenylindole-chromomycin $\mathrm{A}_{3}\left(\mathrm{DAPI}-\mathrm{CMA}_{3}\right)$ staining.

The two species of Pimelodella contained Ag-NOR sites on the submetacentric pair 14, which were located on the short arm. These sites were confirmed by FISH using an $18 \mathrm{~S}$ rDNA probe (Figure 4a and b). A secondary constriction was observed in Pimelodella sp on the short arm of pair 14, and size heteromorphism was detected in this region. The Ag-NOR revealed negative C-bands in both species of Pimelodella, and in I. schubarti the NOR was in an interstitial position on the long arm of the metacentric pair 1, coincident with the secondary constriction, which was confirmed by FISH (Figure 5).

Metaphases stained with $\mathrm{CMA}_{3}$ revealed positive signals on pair 14 in both species of Pimelodella, which corresponded to the Ag-NOR. Treatment with DAPI did not reveal any markings in P. taenioptera, but in Pimelodella sp there was an interstitial marking on the long arm of pair 14, which corresponded to constitutive heterochromatin. In I. schubarti, positive $\mathrm{CMA}_{3}$ signals were detected in the first pair (that corresponded to Ag-NOR sites), but the DAPI signals were negative. 


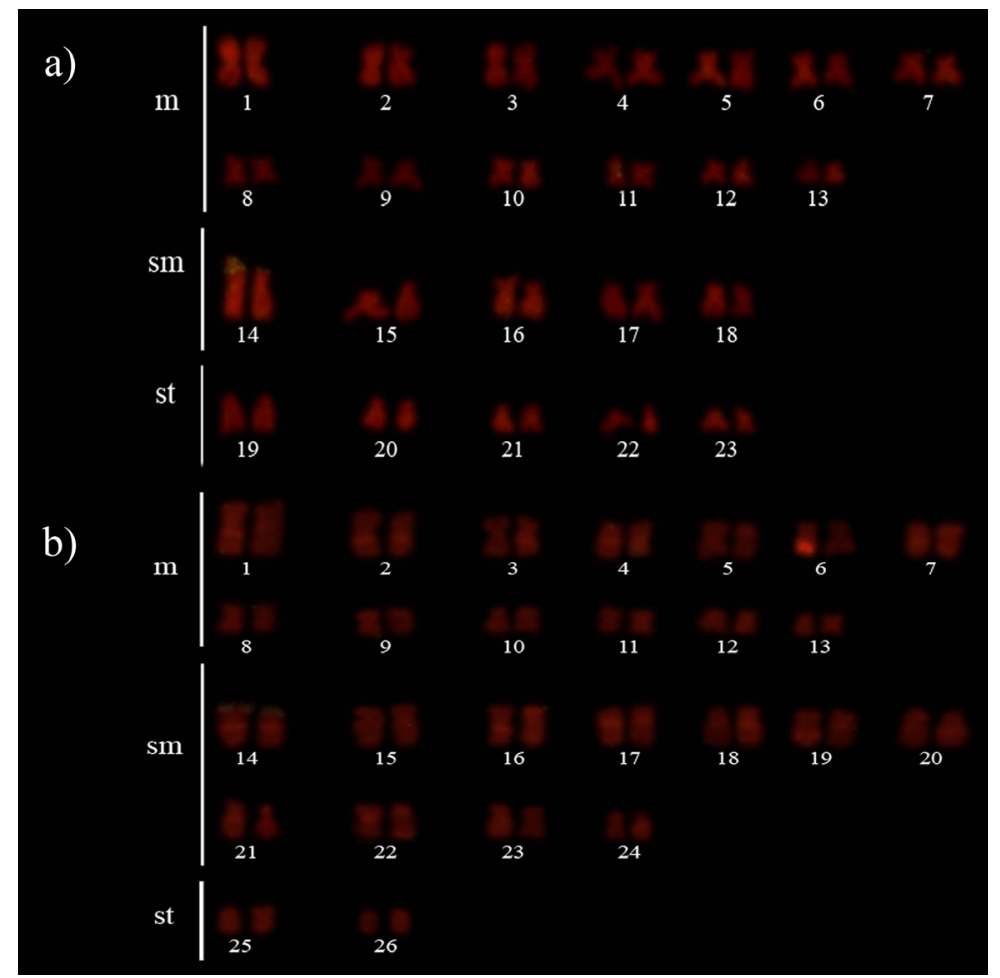

Figure 4. Karyotypes and metaphases of Pimelodella sp after fluorescence in situ hybridization (FISH) using $18 \mathrm{~S}$ rDNA (a) and karyotypes and metaphases of Pimelodella taenioptera after FISH using 18S rDNA (b).

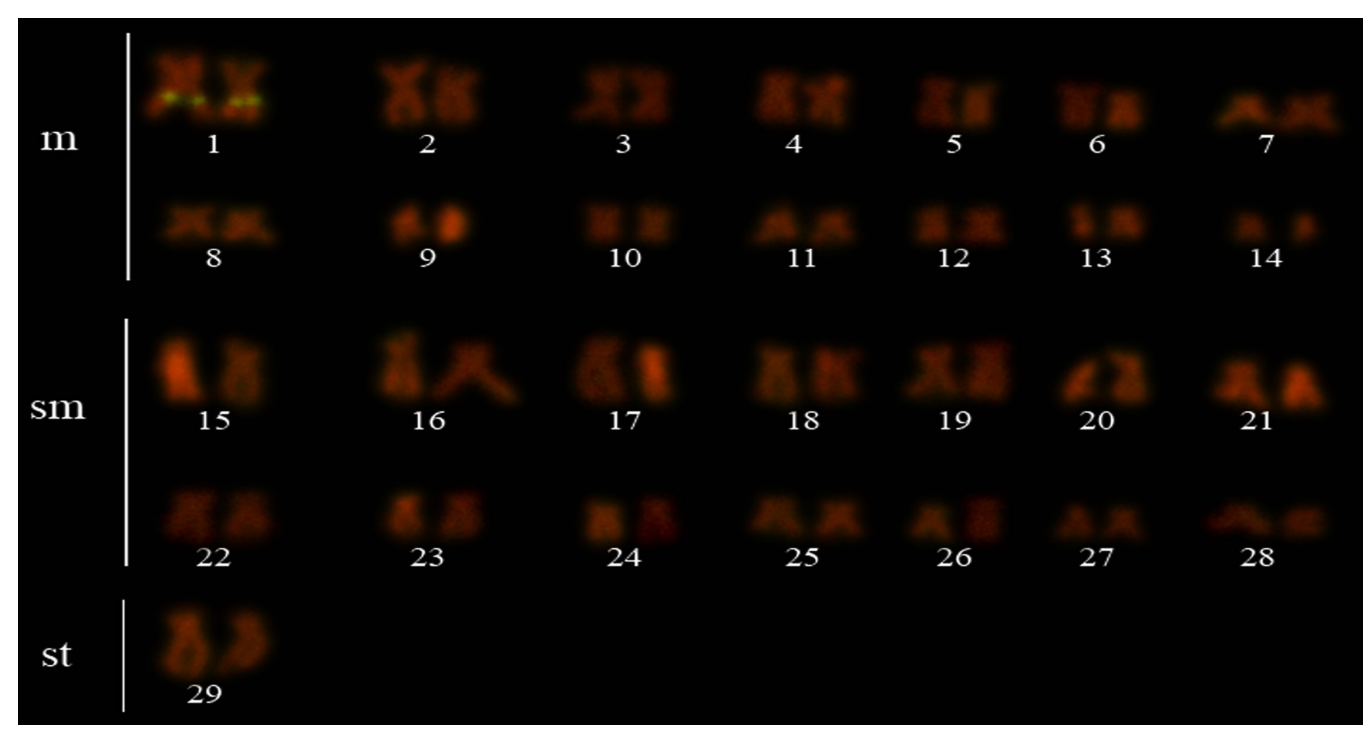

Figure 5. Karyotypes and metaphases of Imparfinis schubarti after fluorescence in situ hybridization (FISH) using $18 \mathrm{~S}$ rDNA. 


\section{DISCUSSION}

The Pimelodella genus is highly diverse in terms of diploid number, with values of $2 \mathrm{n}=46,52$, and 58 chromosomes, depending on the cytogenetic data reported. The $2 \mathrm{n}=46$ diploid number in Pimelodella $\mathrm{sp}$ and $2 \mathrm{n}=52$ in P. taenioptera confirm this variability.

Interspecific variability in diploid number has been recorded previously in Pimelodella: $2 \mathrm{n}=46$ in Pimelodella sp (Toledo and Ferrari, 1976), Pimelodella sp 1 (Vascolcelos and Martins-Santos, 2000), P. meeki (Vidotto et al., 2004), P. boschmai, and P. gracilis (Garcia and Almeida-Toledo, 2010); $2 \mathrm{n}=52$ in Pimelodella sp 2 (Vasconcelos and Martins-Santos, 2000 ) and $P$. aff. avanhandavae (Swarça et al., 2003); and $2 \mathrm{n}=58$ in $P$. kronei, P. transitoria (Almeida-Toledo et al., 1992), and P. lateristriga (Garcia and Almeida-Toledo, 2010). The value of $2 n=56+2$ chromosomes is regarded to be the ancestral diploid number of the Siluriformes (Oliveira and Gosztonyi, 2000), including the Heptapteridae. Most species of Pimelodella have a diploid number of $2 \mathrm{n}=46$; however, $P$. kronei and $P$. transitoria (with $2 \mathrm{n}$ $=58$ ) represent the ancestral form within the group (Vasconcelos and Martins-Santos, 2000).

In the Imparfinis, the diploid number varies from $2 \mathrm{n}=42$ chromosomes, as in I. hollandi (Margarido and Moreira-Filho, 2008), to $2 \mathrm{n}=58$ chromosomes, as in I. mirini (Vissotto et al., 1997), I. piperatus (Vissotto et al., 2001), I. aff. schubarti (Stolf et al., 2004), and $I$. schubarti (Kantec et al., 2009). The values of $2 \mathrm{n}=58$ chromosomes and $\mathrm{NF}=116$, which were found in the present study, are the most common in the genus, being also observed in $I$. mirini (Vissotto et al., 1997), I. piperatus (Vissotto et al., 2001), I. aff. schubarti (Stolf et al., 2004), and I. schubarti (Kantek et al., 2009). Differences in karyotype formula and 2n have been found between different species and populations of Imparfinis; however, the high frequency of species with $2 \mathrm{n}=58$ chromosomes, which is considered not only ancestral for the Heptapteridae but also for the Siluriformes as a whole, indicate that non-Robertsonian chromosomal rearrangements were the most frequent rearrangements made during the karyotypic evolution of the genus.

Among the Heptapteridae, the diploid number of $2 n=42$ is only present in I. hollandi (Margarido and Moreira-Filho, 2008). The predominance of two-armed chromosomes (M, $\mathrm{SM}$, and ST), and the low variation in diploid number $(2 \mathrm{n}=58,2 \mathrm{n}=42)$, suggest that centric fission events were less important than pericentric inversion during the evolutionary history of the group (Borba et al., 2011). According to Borba et al. (2011), a possible plesiomorphic condition of heptapteridan karyotypes would consist of $2 n=58$ chromosomes of the $M$ and SM types and a simple subterminal position of Ag-NORs, with a trend of maintaining this diploid number in most species, while reducing $2 \mathrm{n}$ by successive chromosomal fusion events.

Simple NORs in the Heptapteridae are most frequently located in the terminal position of the short arm, but there is variation between species in chromosome type. NOR size heteromorphism between homologous chromosomes, as observed in Pimelodella sp is common in other Pimelodella species: Pimelodella sp 2 (Vasconcelos and Martins-Santos, 2000), P. aff. avanhandavae (Swarça et al., 2003), P. meeki (Vidotto et al., 2004); and in the Imparfinis: I. cf. piperatus, I. piperatus (Vissotto et al., 2001), and I. schubarti (Stolf et al., 2004). This variation in NOR size is a consequence of the variable number of rDNA genes; therefore, structural modifications in NORs are often attributed to unequal crossing-over mechanisms, transpositions, deletions, and/or duplications involving segments of homologous chromosomes (Castro et al., 1998).

The result of using a $18 \mathrm{~S}$ DNAr probe in I. schubarti in the present study and those 
obtained by Borba et al. (2011), and in I. cf. schubarti (Kantek et al., 2009), were similar in terms of the Ag-NORs. The NORs observed on the long arm of different types of chromosome in this genus can be explained by rearrangements, such as inversions, deletions, and duplications (Borba et al., 2011). A position in the terminal region of a subtelocentric chromosome is probably the ancestral condition, and is similar to that observed in I. hollandi (Margarido and Moreira-Filho, 2008). An interstitial position on metacentric chromosomes, as detected in $I$. mirini (Vissoto et al., 1997), I. aff. schubarti (Stolf et al., 2004, Borba et al., 2011), and I. schubarti (Kantek et al., 2009), is probably a derived condition. The transfer from a submetacentric terminal position to an interstitial position on a pair of metacentric chromosomes probably occurred due to pericentromeric inversion.

In addition to the difference in diploid number, the two species of Pimelodella also exhibited different C-band patterns. While Pimelodella sp contained a small amount of constitutive heterochromatin that was restricted to an interstitial block on the long arm of NOR chromosomes, P. taenioptera exhibited this band on a large number of chromosomes. In general, Heptapterids have small amounts of heterochromatin that are located in terminal and pericentromeric regions (Moraes et al., 2007). Borba et al. (2011) suggested that C-banding is not a good cytological marker method for this group; however, the results found for P. taenioptera demonstrate that heterochromatin constitutes a differential marker in this species in relation to others groups of the Heptapteridae.

Heterochromatin blocks in interstitial positions are infrequent in the Heptapteridae, but are typical of the Imparfinis (Margarido and Moreira-Filho, 2008; Borba et al., 2011). Interstitial blocks of heterochromatin on the long arm of the NOR chromosome in the two Pimelodella species analyzed in this study have also been observed in P. gracilis (Garcia and Almeida-Toledo, 2010). In fish, the presence of heterochromatic blocks interspersed with NORs is a common feature; however, the Pimelodella species analyzed in this study were NOR-C-band negative, and only P. meeki (Borba et al., 2011) exhibits this characteristic in this genus. Among other Siluriformes, C-band-negative NORs have been observed in Pimelodus sp. and Pimelodus ortmanni (Borin and Martins-Santos, 2004), Taunaya bifasciata (Borba et al., 2011), I. schubarti (Kantek et al., 2009), Corumbataia tocantinensis, C. cuestae, Hypoptopoma guentheri, Otocinclus vittatus, Otocinclus flexilis, Otothyris travassosi, Otothyris juquiae, and Schizolecis guntheri (Ferreira et al., 2005).

I. schubarti had a little constitutive heterochromatin that contained centromeric and telomeric markings, which is a characteristic of the Imparfinis. Previous studies on this genus have demonstrated the existence of a few C-band markings in centromeric, pericentromeric, and telomeric positions, as recorded in I. piperatus (Vicente et al., 1994) I. aff. schubarti (Stolf et al., 2004), I. schubarti (Kantek et al., 2009), and I. cf. piperatus (Fenocchio, 1993). In addition, interstitial regions in heterochromatin that correspond with NORs (first pair) and in other chromosomes $(15,21$, and 29) have been observed.

The data obtained in this study for I. schubarti corroborate the results reported by Stolf et al. (2004) for I. aff. schubarti, but differed from those obtained by Kantek et al. (2009) for I. schubarti from the Piumhi River Basin, MG, Brazil. The karyotype formula for that population was $18 \mathrm{~m}+34 \mathrm{sm}+6 \mathrm{st}$, and the NOR was in an interstitial position on a submetacentric chromosome (pair 10), whereas in the present study the NOR was in an interstitial position on the metacentric pair 1. According to Kantek et al. (2009), the distinctive karyotype of I. schubarti from the Piumhi River represents a possible hybridization between I. minutes and I. schubarti, because in the early 1960s several species migrated from the Upper Paraná 
River Basin to the San Francisco Basin, including I. schubarti.

Relationships between NORs and GC-specific fluorochromes have been reported in several groups of fish (Amemiya and Gold, 1986). In most cases, $\mathrm{CMA}_{3}$ staining produces markings that are only coincident with the NORs observed in Pimelodella sp, P. taenioptera, and I. schubarti. In contrast, treatment with AT-specific DAPI results in a generally uniform pattern of chromosomal staining in fish, as we found in the present study; however, Pimelodella sp. did exhibit a DAPI-positive interstitial heterochromatic block. Therefore, the pair 14 this pair could be used as markers in this species for comparative analyses of the group.

The cytogenetic data obtained by this study could be used in future taxonomic revisions of Pimelodella sp. Although Pimelodella sp and P. taenioptera are morphologically very similar, cytogenetic differences in diploid number, chromosomal formula, and C-band pattern suggest that they are different species. Our results corroborate the findings of other studies on this group of fish: the Heptapteridae share some cytogenetic features but each genus has its own unique karyotypic traits. This study also contributes to the karyotypic description of species of the Brazilian Midwest that have been little studied, and provides valuable information for future taxonomic and evolutionary studies.

\section{ACKNOWLEDGMENTS}

We thank the Coordenação de Aperfeiçoamento de Pessoal de Nível Superior (CAPES) for financial support and the Federal University of Mato Grosso for allowing us to use their facilities.

\section{REFERENCES}

Almeida-Toledo LF, Foresti F, Trajano E and Toledo Filho SA (1992). Cytogenetic analysis of the Brazilian blind catfish Pimelodella kronei and of its presumed ancestor Pimelodella transitoria. Caryologia 45: 255-262.

Amemiya CT and Gold JR (1986). Chromomycin $\mathrm{A}_{3}$ stains nucleolar organizer regions of fish chromosomes. Copeia 1: 226-231.

Bertollo LAC, Takahashi CS and Moreira-Filho O (1978). Cytotaxonomic considerations on Hoplias lacerdae (Pisces, Erythrinidae). Rev. Bras. Genet. 2: 103-120.

Bockmann FA and Guazzelli GM (2003). Check list of the freshwaters of south and Central America. In: Family Heptapteridae (Reis RE, Kullander SO and Ferraris Jr. CJ, eds.). Edipucrs, Porto Alegre, pp. 406-431.

Borba RS, Silva EL, Pacheco ACS, Parise-Maltempi PP, et al. (2011). Trends in the karyotypic evolution of the Neotropical catfish family Heptapteridae Bockmann 1998 (Teleostei: Siluriformes). Rev. Fish Biol. Fisheries 22: 509-518.

Borin L and Martins-Santos IC (2004). Study on karyotype and occurrence of B chromosomes in two endemic species of the genus Pimelodus (Siluriformes, Pimelodidae) from the river Iguaçu. Hereditas 140: 201-209.

Burgess WE (1989). An atlas of freshwater and marine catfishes. A preliminary survey of the Siluriformes. THF Publications, Neptune City, New York.

Castro J, Sánchez L and Martinez P (1998). Analysis of the inheritance of NOR size variants in brown trout (Salmo trutta). J. Heredity 89: 264-266.

Cuadrado A and Jouve N (1994). Mapping and organization of highly-repeated DNA sequences by means of simultaneous and sequential FISH and C-banding in 6x-Triticale. Chromosome Res. 2: 231-338.

Eschmeyer WN and Fong JD (2013). Species by family/subfamily. Available at http://research.calacademy.org/research/ ichthyology/catalog/SpeciesByFamily.asp. Accessed January 20, 2013.

Fenocchio AS (1993). Cromossomos supranumerários no gênero Rhamdia (Pisces). Caracterização cromossômica e considerações sobre a evolução cariotípica nos Siluroidei. Doctoral thesis, Universidade Federal de São Carlos, UFSCAR, São Carlos.

Ferraris CJ (2007). Checklist of catfishes, recent and fossil (Osteichthyes: Siluriformes), and catalogue of siluriform primary types. Zootaxa 1418: 1-628. 
Ferreira DC, Chiachio MC, Takako AK, Andreata AA, et al. (2005). Comparative cytogenetics of nine species of Hypoptopomatinae (Teleostei: Siluriformes: Loricariidae): the importance of structural rearrangements in chromosome evolution. Caryologia 58: 387-395.

Garcia C and Almeida-Toledo LF (2010). Comparative chromosomal analyses in species of the genus Pimelodella (Siluriformes, Heptapteridae): occurrence of structural and numerical polymorphisms. Caryologia 63: 32-40.

Heslop-Harrison JS, Schawarzacher K, Anamthaw-Jónsson AR, Leitch MS, et al. (1991). In situ hybridization with automated chromosome denaturation. Technique-J. Method. Mol. Cell. Biol. 3: 109-116.

Howell WM and Black DA (1980). Controlled silver-staining of nucleolus organizer regions with a protective colloidal developer: a 1-step method. Experientia 36: 1014-1015.

Kantek DLZ, Peres WAM, Buckup PA and Moreira-Filho O (2009). Cytogenetics of Imparfinis schubarti (Siluriformes: Heptapteridae) from the Piumhi drainage, a diverted river in Minas Gerais State, Brazil. Zoologia 4: 733-738.

Levan A, Fredga K and Sandberg AA (1964). Nomenclature for centromeric position on chromosomes. Hereditas 52: 201-220.

Lui RL, Blanco DR, Margarido VP and Moreira-Filho O (2009). First description of B chromosomes in the family Auchenipteridae, Parauchenipterus galeatus (Siluriformes) of the São Francisco River basin (MG, Brazil). Micron 40: $552-559$.

Lundberg JG, Bornbush AH and Mago-Leccia F (1991). Gladioglanis conquistador N. sp. from Ecuador with diagnoses of the subfamilies Rhamdiinae Bleeker and Pseudopimelodidae N. Subf. (Siluriformes, Pimelodidae). Copeia 1: 190-209.

Margarido VP and Moreira-Filho O (2008). Karyotypic differentiation through chromosome fusion and number reduction in Imparfinis hollandi (Ostariophysi, Heptapteridae). Genet. Mol. Biol. 31: 235-238.

Moraes VPO, Cereali SS, Froehlich O and Dias AL (2007). Cytogenetic characterization of Rhamdia quelen (Siluriformes: Heptapteridae) from the Bodoquena Plateau, Mato Grosso do Sul, Brazil. Genet. Mol. Res. 3: 627-633.

Oliveira C and Gosztonyi AE (2000). A cytogenetic study of Diplomystes mesembrinus (Teleostei, Siluriformes, Diplomystidae) with a discussion of chromosome evolution in Siluriformes. Caryologia 53: 31-37.

Pinna MCC (1998). Phylogeny and classification of Neotropical fishes. In: Phylogenetic relationships of Neotropical Siluriformes (Teleostei: Ostariophysi): historical overview and synthesis of hypotheses. (Malabarba LR, Reis RE, Vari RP, Lucena ZMS, et al., eds.). Ediprucrs, Porto Alegre, 279-330.

Schmid M (1980). Chromosome banding in Amphibia. IV. Differentiation of GC- and AT-rich chromosome region in Anura. Chromosoma 77: 83-103.

Schweizer D (1976). Reverse fluorescent chromosome banding with chromomycin and DAPI. Chromosoma 58: 307-324.

Stolf R, Swarça AC, Guiliano-Caetano L and Dias AL (2004). Analyses of karyotype and nucleolus organizer regions of Imparfinis aff. schubarti (Siluriformes, Pimelodidae) of the Tibagi river basin, Paraná, Brazil. Caryologia 57: 348-352.

Sumner AT (1972). A simple technique for demonstrating centromeric heterochromatin. Exp. Cell Res. 75: 304-306.

Swarça AC, Vidotto AP and Dias AL (2003). Cytogenetic characterization of Pimelodella aff. avanhandavae (Siluriformes, Pimelodidae) from Tibagi River (Paraná State, Brazil). Caryologia 56: 421-425.

Toledo V and Ferrari I (1976). Estudo citogenético de Pimelodella sp. e Rhamdia hilarii (Pimelodinae, Pimelodidae, Pisces): Cromossomo marcador. Cientifica 4: 120-123.

Vasconcelos C and Martins-Santos IC (2000). Chromosome polymorphism in species of the Pimelodidae family (Pisces, Siluriformes). Hereditas 132: 103-109.

Vicente MRR, Margarido VP and Galetti Jr PM (1994). Estudos cromossômicos em Imparfinis piperatus (Pisces, Siluriformes) do riacho São João (Bacia do Leste). In: V Simpósio de Citogenética e Genética Evolutiva Aplicada de Peixes Neotropicais, Botucatu, p. 17.

Vidotto AP, Swarça AC, Fenocchio AS and Dias AL (2004). Cytogenetic studies in three Pimelodella meeki populations (Pisces, Pimelodidae) from Tibagi River Basin (Brazil). J. Heredity 95: 517-520.

Vissotto PC, Foresti F and Oliveira C (1997). A ZZ/ZW sex chromosome system in Imparfinis mirini (Pisces, Siluriformes). Cytologia 62: 61-66.

Vissotto PC, Foresti F and Oliveira C (2001). Karyotypic characterization of two species of the genus Imparfinis (Teleostei, Siluriformes, Heptapteridae). Chromosome Sci. 5: 97-103. 